\title{
Evaluation of the Forest Reclamation of the Anthroposoil Dump at the Bílina Mines Created from Marlstone
}

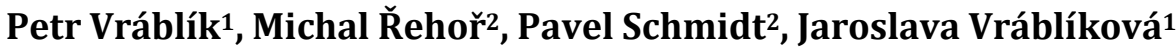 \\ ${ }^{1}$ Department of Natural Sciences, Faculty of Environment, J. E. Purkyně University in Ústí nad Labem, \\ Ústí nad Labem, Czech Republic \\ ${ }^{2}$ Research Institute for Brown Coal in Most, Most, Czech Republic \\ Email: petr.vrablik@ujep.cz
}

How to cite this paper: Vráblík, P., Řehoř, M., Schmidt, P. and Vráblíková, J. (2018) Evaluation of the Forest Reclamation of the Anthroposoil Dump at the Bílina Mines Created from Marlstone. Open Journal of Soil Science, 8, 360-367.

https://doi.org/10.4236/ojss.2018.812026

Received: November 6, 2018

Accepted: December 22, 2018

Published: December 25, 2018

Copyright (c) 2018 by authors and Scientific Research Publishing Inc. This work is licensed under the Creative Commons Attribution International License (CC BY 4.0).

http://creativecommons.org/licenses/by/4.0/

\begin{abstract}
When reclaiming the surface of the Radovesická dump in the North Bohemian brown coal basin, the most commonly used marls and marlstones are extracted in the foreland of filled-in territory. The most frequent reclamations are the formation of overgrown and humus anthroposoil. The soil properties of the anthroposoils for forestry purposes and the growth vitality of a broader assortment of woody plants in the age of $12-14$ years are evaluated. It has been found that the very good growth vitality on these anthroposoils is shown by most of the trees of domestic origin (Populus nigra L., Acer pseudoplatanus L., Pinus sylvestris L., Alnus glutinosa (L.) Gaertn., Fraxinus excelsior L., Betula verrucosa Ehrh., Quercus robur L., Tilia cordata Mill.), including some of the tree species introduced (Larix decidua L., Pinus nigra Arn.) and reclamations of atypical atrophic soil horizons did not negatively affect their development.
\end{abstract}

\section{Keywords}

Anthroposoil Landfill, Forest Reclamation, Marlstone, Loamy Clay, Soil Properties, Growth Vitality

\section{Introduction}

A considerable proportion of the concealed overlying deposits in the surface mining of brown coal, especially in the area of the Bílina mines in the North Bohemian coal basin, also form the structurally heterogeneous substrates composed of sands, silt, gravel, claystone, burnt clays, and often the rocks already 
have coal seams with a higher content of coal impurities [1] [2] [3]. The reclamation measures needed when adjusting their soil properties prior to afforestation are more demanding, taking into account both the criteria of their hydro-physical (anti-erosion) and the chemical treatment. Most of the reclamation concepts of the land treatment affected by these overlaying rocks assume a variation in the formation of anthroposoils [4] or a counter-erosion [5] variation of the creation of anthropomorphic humus. When reclaiming the soil properties of these dump substrates, reclamation technologies are currently being used, where at higher slope conditions only the surface of the dump is layered over by available fertilizer soils, most commonly selectively hidden loess clay and a minimum thickness of $0.3 \mathrm{~m}$, or the creation of combined overlays when the surface of the dump is first overlaid with marl rocks with a thickness of about $0.3 \mathrm{~m}$ and then with a cover of a humus horizon (topsoil) with a thickness of about $0.2 \mathrm{~m}$. In the more favorable slope ratios, the reclamation variant is also used, where the mixing soil is mixed with the available land development sorbent (loess clay, marl rocks, lower quality humus horizons) applied at a rate of about $2000 \mathrm{t} / \mathrm{ha}$ to a total depth of $0.3-0.4 \mathrm{~m}$. Depending on the soil conditions, reclaiming and other measures, which especially include the application of various wastes of organic origin, or industrial compost and sludge from wastewater treatment plants have also been verified from the waste water treatment plant. Similar measures for the treatment of soil properties on anthroposoils are also assessed [6] [7] [8] [9] [10].

\section{Methodology}

\subsection{Evaluation of Anthroposoil Reclamation Variants}

Variant " $A$ " ( $X: 984793, Y: 778111, Z: 299,4)$; includes the territory of the $1^{\text {st }}$ stage of reclamation of the Radovesická dump (Figure 1), with the technical reclamation completed between 1992-1993. The technological process of reclaiming this area consisted of the introduction of muddy rocks at a rate of about $2000 \mathrm{t} / \mathrm{ha}$, their spreading and crossing into the soil profile with a very deep tillage. This modified surface soil horizon was overlaid again with mixed rock at a rate of about $2000 \mathrm{t} / \mathrm{ha}$ and also technologically similar to the previous one. $\mathrm{Va}$ riant “ $B$ " (X: 984912, Y: 778963, Z: 311, 2); includes the territory of the III. stage of reclamation of the Radovesická dump, with the technical reclamation completed between 1993-1994. The technological process of the reclamation of this area consisted of depositing marlstone at a rate of $2000-3000 \mathrm{t} / \mathrm{ha}$, spreading it out, followed by overlaying this layer with loess earth at a rate of $2000-3000$ $\mathrm{t} / \mathrm{ha}$ and plowing it into the soil profile with a very deep plow. Variant " $C$ " ( $X$ : 985365, Y: 777563, $Z: 315,8$ ); includes the territory of the 1st stage of the reclamation of the Braňany dump with the technical reclamation in the years 1993-1994. The technological process of the reclamation of this area consisted of its overlaying with a cover of a humus horizon (topsoil) with a total thickness of $0.2-0.3 \mathrm{~m}$. 


\subsection{Evaluation of the Growth Vitality of Forest}

Assessing the growth vitality of forest tree species (Populus nigra L., Populus nigra var. Pyramidalis L., Larix decidua L., Betula verrucosa Ehrh., Fraxinus excelsior L., Tilia cordata Mill., Pinus nigra Arn., Acer pseudoplatanus L., Alnus glutinosa (L.) Gaertn., Picea omorica L., Pinus murrayana var. latifolia, Quercus robur L., Pinus sylvestris L., Picea pungens L.), based on determining the dendrometric quantities (total height, taking into account the thickness $d_{1,3}$ ) for 20 100 specimens from all tree species represented, (with regard to the frequency of their representation in the stand), in the case of Betula verrucosa Ehrh. (variants “ $A$ " and " $B$ ") and Populus nigra L. (variant " $B$ ") is the evaluation of individuals from the stage of primary succession. The statistical evaluation of growth vitality of the trees (using One-Factor Anova) was performed only for the taxa where the dendrometric quantity (total height) was captured in more than 30 specimens. As a control area for comparison of the growth vitality of forest trees on made of clustered rocks, a forest reclamation with a similar age was found, located on humus anthroposoils (overlap of the dump soil with a thickness of $0.2-0.3 \mathrm{~m}$ ) in the area of the first stage of the anthroposoils Braňany dump (variant “ $C$ ").

\subsection{Evaluation of Anthroposoil Quantities}

With respect to the soil samples collected (Kopecky cylinders of $100 \mathrm{~cm}^{3}$ ) from characteristic soil horizons, i.e. from the substrate affected and not influenced by the absorption rate of the sorbent, the grain composition, the soil reaction, the content of organic substances and carbonates, the absorption properties, the content of the acceptable nutrients $(\mathrm{P}, \mathrm{K}, \mathrm{Mg}, \mathrm{Ca})$, maximum capillary water capacity, maximum capillary absorption, porosity and bulk density were determined at the laboratory. The coefficient of the hydraulic conductivity is determined on the basis of field infiltration measurements using the Guelph Permeameter (Figure 1).

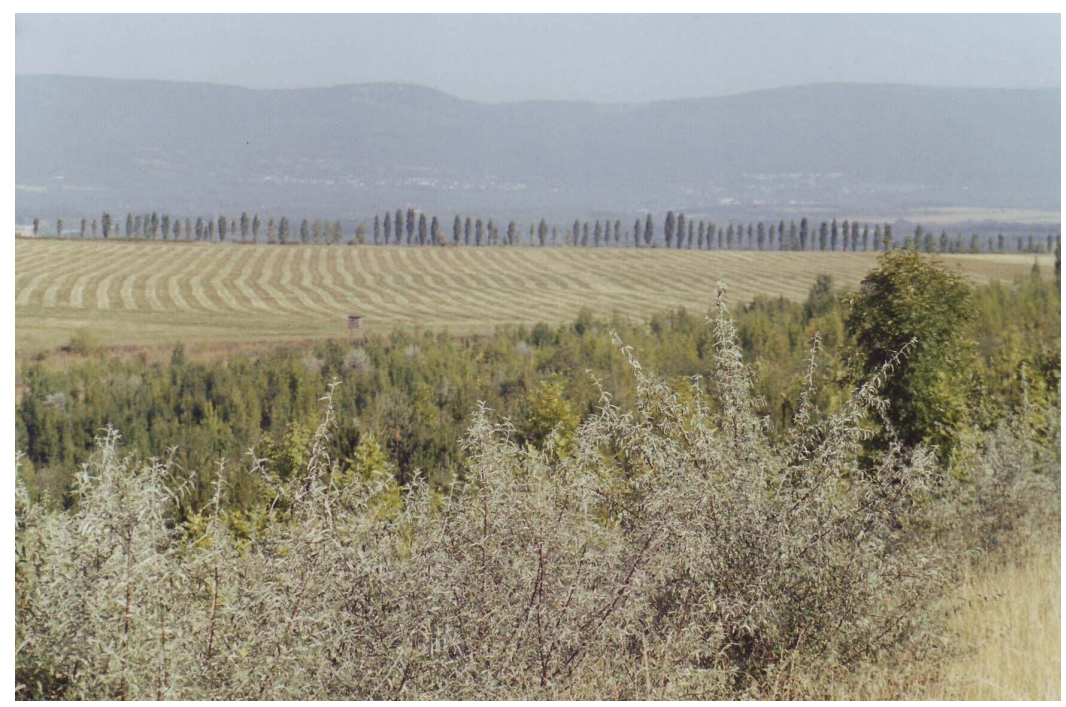

Figure 1. The wooded area of the Radovesice I dump. 


\subsection{Evaluating the Soil Properties of Anthroposoils}

Reclamation variant " $A$ "; the soil-forming substrate of the modified horizons via reclamation $(0-0.5 \mathrm{~m})$, can be characterized as a silt loam carbonate and granularity as a clay soil. The soil exchange reaction is slightly alkaline, the substrate has a very low content of organic substances, carbonate content is marl, cation exchange capacity is medium, absorption is completely saturated, has low phosphorus content, potassium, good magnesium, and very high calcium. From a hydro-physical point of view, it is a favorable variant for the surface treatment for dumps which is structural, strongly water-bearing and slightly porous. The substrate consisting only of dump soil (more than $0.5 \mathrm{~m}$ ) may be petrographically characterized as siltstone and granularly as sand to sandy clay. The soil is slightly alkaline, the substrate has a medium content of organic matter (the presence of coal), is slightly calcified, cation exchange capacity is medium, absorption is completely saturated, low phosphorus, high potassium, very high magnesium, and high calcium and slightly porous.

Reclamation variant " $B$ "; the soil-forming substrate of the modified horizon by reclamation $(0-0.4 \mathrm{~m})$ can be characterized petrographically as dusty claystone and grain-like clay. The soil exchange reaction is slightly alkaline, the substrate has a low organic content, is calcium, the cation exchange capacity is high, absorption is completely saturated, has a low content of phosphorus, potassium, very high magnesium, and calcium. From a hydro-physical point of view, it is a favorable variant for the surface treatment of the dump which is structural, strongly water-bearing and slightly porous. The soil horizon of $0.4-0.6 \mathrm{~m}$ can be petrographically characterized as dusty clayey carbonate and granular as clay soil. The soil exchange reaction is slightly alkaline, the substrate has a low content of organic substances, carbonate content is marl, cation exchange capacity is medium, absorption is completely saturated, has low phosphorus content, potassium, very high magnesium and calcium, the soil is strongly watertight medium porous. The soil-forming subsurface consisting of dump soil (more than $0.6 \mathrm{~m}$ ) can be petrographically characterized as dusty claystone and grain-like clay. Soil exchange reaction is slightly alkaline, the substrate has a very low content of organic substances, is carbon-free, the cation exchange capacity is very low, absorption is completely saturated, has low phosphorus content, good potassium, very high magnesium, and low calcium, is moderately water-porous.

Reclamation variant " $C$ ", the humus horizon $(0-0.3 \mathrm{~m})$ formed from the overgrown horizon, can be petrographically characterized as dusty claystone and grain-like as clay to loam-clay, the soil reaction is neutral, the soil is slightly limestone, has a high organic content, the cation exchange capacity is high, it is completely saturated with absorption, has a low content of phosphorus, high potassium, magnesium and calcium, and, from the point of view of hydro physics, it is a favorable variant for surface treatment which is structural, strongly waterproof and medium porous. The soil horizon $(0.3-0.8 \mathrm{~m})$ which forms the dump substrate can be characterized petrographically as dusty claystone, grain-like as 
clay to loam-clay, the soil reaction is exchangeable neutral, the soil is carbon-free, with low organic matter, the cationic exchange capacity is low, absorption is completely saturated, has a low phosphorus content, potassium-rich, very high magnesium and calcium-friendly. The soil properties of the assessed reclamation variants are set out in Table 1 and Table 2.

\subsection{Growth Vitality of Forest Tree Species on Anthroposoils}

The unrivaled best growth vitality on the basis of the established dendrometric quantities is shown on the dump substrates reclaimed by treatment with high

Table 1. Grain composition.

\begin{tabular}{|c|c|c|c|c|c|c|}
\hline \multirow{2}{*}{$\begin{array}{l}\text { Reclamation } \\
\text { variant }\end{array}$} & \multirow{2}{*}{$\begin{array}{l}\text { Soil horizon } \\
(\mathrm{cm})\end{array}$} & \multicolumn{5}{|c|}{ Content of category's granularity (\%) } \\
\hline & & $<0.001 \mathrm{~mm}$ & $<0.01 \mathrm{~mm}$ & $0.01-0.05$ & $0.05-0.25$ & $0.25-2.0$ \\
\hline \multirow{4}{*}{ "A" } & $0-10$ & 24.5 & 59.5 & 18.5 & 14.3 & 7.7 \\
\hline & $10-30$ & 28.8 & 64.3 & 15.2 & 13.7 & 6.7 \\
\hline & $30-50$ & 24.6 & 55.7 & 15.5 & 19.6 & 9.2 \\
\hline & $50-80$ & 2.8 & 6.5 & 2.9 & 4.5 & 86.1 \\
\hline \multirow{4}{*}{ “B” } & $0-10$ & 26.1 & 48.9 & 17.2 & 18.1 & 15.8 \\
\hline & $10-40$ & 28.3 & 43.1 & 20.7 & 17.2 & 19.0 \\
\hline & $40-70$ & 30.2 & 70.7 & 18.6 & 8.1 & 2.6 \\
\hline & $70-90$ & 20.2 & 41.2 & 21.7 & 32.3 & 4.8 \\
\hline \multirow{3}{*}{ “C” } & $0-10$ & 30.1 & 44.6 & 25.0 & 8.2 & 22.2 \\
\hline & $10-30$ & 31.3 & 49.3 & 24.6 & 9.0 & 17.1 \\
\hline & $30-80$ & 22.2 & 45.3 & 21.1 & 13.8 & 19.8 \\
\hline
\end{tabular}

Table 2. Chemical and other soil properties.

\begin{tabular}{ccccccccccc}
\hline \multirow{2}{*}{$\begin{array}{c}\text { Reclamation } \\
\text { variant }\end{array}$} & $\begin{array}{c}\text { Soil horizon } \\
(\mathrm{cm})\end{array}$ & $\mathrm{pHKCl}$ & $\begin{array}{c}\mathrm{CaCO}_{3} \\
(\%)\end{array}$ & $\mathrm{C}_{\mathrm{ox}}(\%)$ & $\begin{array}{c}\mathrm{CEC} \\
(\mathrm{cmol}+\mathrm{kg})\end{array}$ & \multicolumn{3}{c}{$\begin{array}{c}\text { Acceptable nutrients } \\
\text { Mehlich III }(\mathrm{mg} / \mathrm{kg})\end{array}$} \\
\hline & $0-10$ & 7.2 & 26.0 & 1.28 & 12.5 & 2.3 & 155 & 268 & 37,869 \\
& $10-30$ & 7.4 & 28.0 & 0.32 & 9.4 & 4.3 & 116 & 199 & 38,847 \\
“A” & $30-50$ & 7.6 & 26.0 & 0.44 & 9.9 & 1.0 & 89 & 225 & 36,713 \\
& $50-80$ & 7.6 & 2.1 & 0.11 & 5.0 & 6.7 & 94 & 267 & 6120 \\
& $0-10$ & 7.1 & 3.0 & 1.22 & 23.1 & 12.1 & 138 & 259 & 9690 \\
& $10-40$ & 7.3 & 4.2 & 0.98 & 21.1 & 7.5 & 158 & 353 & 13,238 \\
& $40-60$ & 7.7 & 43.0 & 0.11 & 13.3 & 2.3 & 102 & 400 & 38,483 \\
& $60-90$ & 7.8 & 0.2 & 0.60 & 7.5 & 4.1 & 131 & 565 & 1490 \\
& $0-10$ & 7.0 & 1.0 & 2.61 & 30.6 & 15.3 & 480 & 360 & 6010 \\
& $10-30$ & 7.1 & 1.2 & 1.90 & 29.1 & 14.9 & 463 & 384 & 6343 \\
& $30-80$ & 7.0 & 0.1 & 0.31 & 12.9 & 6.4 & 91 & 209 & 1796 \\
\hline
\end{tabular}


amounts of marlstone Populus nigra L. and Populus nigra L., var. Pyramidalis L. These trees grow further in the growth prosperity are rivaled by Larix decidua L., Pinus sylvestris L. and depending on the soil properties created by anthroposoil Alnus glutinosa (L.) Gaertn., Acer pseudoplatanus L. and Betula verrucosa Ehrh. Another significant group of trees in terms of reclamation that can be utilized in the afforestation of these anthroposoils with lower taxonomical quantities are Fraxinus excelsior L., Pinus nigra Arn., Quercus robur L. and Tilia cordata Mill. In terms of both the reclamation and growth, it can be considered as a minor species of artificial planting of the origin introduced by Pinus murrayana var. latifolia, Picea pungens L. and Picea omorica L. The dendrometric quantities determined are shown in Table 3.

\section{Conclusions}

The long-term pedological and vegetation investigations carried out on the dump substrates reclaimed using marlstone can be summarized by these more general conclusions. The use of $20 \%-40 \%$ of marlstone in the treatment of soil properties of sandy soils is the formation of sandy alluvium and $60 \%-80 \%$ share of marlstone and the formation of clay soil. The amount of marlstone used for the reclamation $(20 \%, 40 \%, 60 \%$, and $80 \%)$ represents a similar increase in the soil alkalinity. Increasing the amount of marlstone (more than $20 \%$ ) represents a further insignificant increase in the carbonate content, cation exchange capacity, phosphorus, potassium, and magnesium in terms of forestry. Using a $20 \%$ share of marlstone is also a positive treatment for the water management but increasing doses are no longer involved in a more significant treatment of this soil attribute. The most important factor in the use of marlstone for the reclamation purposes in the dumps, regardless of the textural character of the treated soils, is the presence of the substrates of coal seams, i.e. the increased content of variously eroded coal and pyrite which in the soil-forming process is extremely unfavorable for vegetation and a worsening hydro-physical and chemical status (after excessively drying out and having low absorption rates, adverse erosion properties, an increase in soil acidity). Due to the inaccessibility of suitable mechanical means which can be used in mixing damp soil with marlstone on the slopes with a slope angle of up to $16 \%$, a variant was also used where only the surface of damp was covered with marlstone with a thickness of $0.2-0.3 \mathrm{~m}$, or this soil horizon was treated with topsoil or loess loam with a thickness of $0.2 \mathrm{~m}$. According to current knowledge on the welfare of forest tree growth at this site, this variant can be considered usable in the most extreme climatic conditions.

During the afforestation of the dumps treated by the reclamation methods using a high amount of marstone, a relatively wide range of tree species of the origin of the home (Populus nigra L., Acer pseudoplatanus L., Pinus sylvestris L., Alnus glutinosa (L.) Gaertn., Fraxinus excelsior L., Betula verrucosa Ehrh., Quercus robur L., Tilia cordata Mill.), including some of the species introduced (Larix decidua L., Pinus nigra Arn.) which also exhibit considerable ecovalence 
Table 3. Growth vitality of forest trees.

\begin{tabular}{|c|c|c|c|}
\hline Wood species & Reclamation status & Thickness $\mathrm{d}_{1,3}(\mathrm{~cm})$ & Height (m) \\
\hline \multirow{2}{*}{ Pinus nigra Arn. } & "A" & 10.3 & 5.1 \\
\hline & "B" & 11.0 & 4.8 \\
\hline \multirow{2}{*}{ Larix decidua L. } & "A" & 9.5 & 7.5 \\
\hline & "B" & 9.0 & 7.7 \\
\hline \multirow{2}{*}{ Picea pungens } & "A" & 3.9 & 2.9 \\
\hline & “B” & 3.3 & 2.7 \\
\hline \multirow{2}{*}{ Acer pseudoplatanus $\mathrm{L}$. } & “A” & 4.2 & 4.7 \\
\hline & "B" & 5.6 & 5.9 \\
\hline \multirow{2}{*}{ Quercus robur $\mathrm{L}$. } & “A” & 4.1 & 4.9 \\
\hline & "B" & 4.4 & 4.4 \\
\hline \multirow{2}{*}{ Tilia cordata Mill. } & "A" & 5.8 & 4.6 \\
\hline & "B" & 6.9 & 4.4 \\
\hline \multirow{2}{*}{ Fraxinus excelsior $\mathrm{L}$. } & “A” & 4.6 & 5.2 \\
\hline & “B” & 4.2 & 4.8 \\
\hline \multirow{2}{*}{ Alnus glutinosa (L.) Gaertn. } & “A” & 4.8 & 5.0 \\
\hline & "B" & 9.5 & 6.1 \\
\hline \multirow{2}{*}{ Tilia cordata Mill. } & "B" & 6.9 & 4.4 \\
\hline & "C" & 7.1 & 4.2 \\
\hline \multirow{2}{*}{ Acer pseudoplatanus } & "B" & 5.6 & 5.9 \\
\hline & “C” & 7.0 & 7.2 \\
\hline \multirow{2}{*}{ Fraxinus excelsior $\mathrm{L}$. } & "B" & 4.2 & 4.8 \\
\hline & "C" & 4.5 & 5.0 \\
\hline \multirow{2}{*}{ Alnus glutinosa (L.) Gaertn. } & "B" & 9.5 & 6.1 \\
\hline & "C" & 8.6 & 6.9 \\
\hline Pinus sylvestris $\mathrm{L}$. & "B" & 8.4 & 6.4 \\
\hline Picea omorica L. & "A" & 4.4 & 4.2 \\
\hline \multirow{2}{*}{ Betula verrucosa Ehrh. } & "A" & 8.9 & 8.5 \\
\hline & "B" & 10.8 & 8.1 \\
\hline Pinus murrayana var. latifolia & "A" & 4.0 & 3.6 \\
\hline \multirow{2}{*}{ Populus nigra L. } & “A" & 19.3 & 18.1 \\
\hline & "B" & 18.6 & 14.2 \\
\hline Populus nigra L. var. pyramidalis & "A" & 17.5 & 15.7 \\
\hline
\end{tabular}

to the profiled soil properties of anthroposoils. In the case of woody plants that respond more significantly to the more favorable soil anthroposoils (application of topsoil and loess), only Acer pseudoplatanus L. and Alnus glutinosa (L.) Gaertn can be considered (Table 3). 


\section{Acknowledgements}

This article was supported by project QJ1520307 entitled "Sustainable Forms of Management in an Anthropogenically Burdened Region". This project was realized with financial support from state budget resources through the KUS program, Ministry of Agriculture of the Czech Republic.

\section{Conflicts of Interest}

The authors declare no conflicts of interest regarding the publication of this paper.

\section{References}

[1] Kohel, J. and Čermák, P. (2004) Soil-Forming Processes of Anthropic Soils Generated on the Dumps in the Area of the North Bohemian Basin. Soil and Water, Research Institute for Soil and Water Conservation, Prague, 33-50.

[2] Ondráček, V., Řehoř, M. and Lang, T. (2003) Historie, Gegenwart und Perspektiven der Rekultivierung auf dem Gebiet des Bergbaubetriebes Doly Bílina. Surface Mining-Braunkohle \& Other Minerals, 90-101.

[3] Řehoř, M., Lang, T. and Eis, M. (2006) Application of New Methods in Solving Current Reclamation Issues of Severočeské Doly, a.s. Location. Surface Mining-Braunkohle \& Other Minerals, 283-286.

[4] Němeček, J. (2001) Taxonomic Classification System of Soils of the Czech Republic. Czech University of Life Sciences, Prague, 79.

[5] Čermák, P. and Ondráček, V. (2007) Analysis of Erosion Processes in the North Bohemian Basins Spoil Tips without Vegetation. Uhlí rudy, 6-8.

[6] Katzur, J., Böcker, L., Stähr, F. and Mertzig, C.C. (1998) The Impact of Melioration Depth on Forest Growth on Mine Spoils Afforested for the First Time. Beiträge für Forstwirtschaft und Landschaft sökologie, 32, 170-178.

[7] Schulze-Bierbach, A. and Plattenberg, F. (1998) Silvicultural Challenges in Federál German Forests. AFZ/Der Wald, Allgemeine Forst Zeitschrift für Waldwirtschaft und Umweltvorsorge, 53, 898-900.

[8] Weber, E., Klem, D., Hüttl, R.F. and Schaft, W. (1999) Forestry on Spoil Heap Sites. AFZ/Der Wald, Algemeine Forst Zeitschrift für Waldwirtschaft und Umweltvorsorge, 54, 1324-1343.

[9] Schaaf, W., Gast, M., Wilden, R., Scherzer, J., Blechschmidt, R. and Hüttl, R.F. (1999) Temporal and Spatial Development of Soil Solution Chemistry and Element Budgets in Different Mine Soils of the Lusatian Lignite Mining Area. Plant and Soil, 213, 169-179. https://doi.org/10.1023/A:1004542205087

[10] Alonso, F.J., Viladrich, O., Serrasolses, I. and Graça, O. (2000) Use of Sewage Sludge for Restoration of Degraded Lands. Man and Soil at the Third Millenium. Proceedings International Congress of the European Society for Soil Conservation, Valencia, Spain, 28 March-1 April 2000, 2159-2166. 